\title{
Selecting priority areas to conserve Psittacines in the Brazilian cerrado: minimizing human-conservation conflicts
}

\author{
MÍRIAM PLAZA PINTO, PABLO VINÍCIUS CLEMENTE MATHIAS, \\ DANIEL BLAMIRES, JOSÉ ALEXANDRE FELIZOLA DINIZ-FILHO and \\ LUIS MAURICIO BINI
}

\section{Summary}

The rapid destruction of habitat in biodiversity hotspots calls for the urgent formulation of conservation strategies. In this study, macro-scale biogeographical data for 33 species of Psittacines were used to select networks of priority areas, using an algorithm based on the complementarity concept. Human population size was also incorporated as a cost in the selection process, and the two networks of priority areas (with and without cost) were compared. In the comparison the number of cells selected to represent all species did not differ, but a rearrangement occurred between them. Two of the four cells were located in the same place, and the others changed location but stayed aggregated within the same regions. The study shows that it is possible to minimize human population size and represent all species in a network of priority areas.

\section{Introduction}

Irreversible losses of biological diversity continue as a complex response to environmental changes caused by human demands that, in turn, are driven by population growth and the power of technological expansion (Vitousek et al. 1997). Balmford et al. (2002) reported that the mean rate of land-use change within each of the Earth's biomes is about $1.2 \%$ per year. Several parrot species are also globally threatened, such as the Hyacinth Macaw Anodorhynchus hyacinthinus, classified as Endangered and Yellow-faced Parrot Amazona xanthops, which is Near Threatened (BirdLife International 2004). Unfortunately, several conflicts between conservation and development have to be considered when selecting networks of priority areas (Balmford et al. 2001, Chown et al. 2003, Lawler et al. 2003). It is useful to minimize conflicts by using variables that indicate interests in the land-use of the areas other than conservation in the selection procedure for reserves.

The efficient selection of sites can be defined as an optimization problem with the goal of protecting all conservation targets with minimum resource expenditure (minimum number of areas; Lawler et al. 2003). Currently, sites are most often selected using a predefined algorithm based on the concept of complementarity (Margules et al. 1988, Csuti et al. 1997, Howard et al. 1998, Araújo and Williams 200o). Complementarity is a measure of the degree to which a site contributes to the representation of previously unrepresented species (Pressey et al. 1993). Some reserve selection studies also incorporate human population size or indicators of human population size to minimize conservation conflicts (Balmford et al. 2001, Chown et al. 2003, Lawler et al. 2003). 
The Cerrado biome is a mosaic of different habitat types that range from open vegetation areas to dense forests; it harbours approximately 837 bird species, 759 of them known or assumed to breed in this region (Silva 1995a). Thus, many species are probably harmed by destruction of natural habitats and by the recent expansion of agriculture in the region (Silva 1995b, Cavalcanti 1999, Tubelis and Cavalcanti 2000). At least $67 \%$ of the original area of this biome has already been converted to intensive human use, and current estimates place conversion at $80 \%$ (Myers et al. 2000, Cavalcanti and Joly 2002; Klink and Machado 2005). These rates of change call for urgent biodiversity conservation strategies for this biome to avoid the 'extinction crisis' led by habitat destruction in hotspots (Brooks et al. 2002). The conservation of the Cerrado has been neglected until very recently, since it was sparsely inhabited until the mid-twentieth century and the original Cerrado had little apparent economic value. The mechanization of Brazilian agriculture after 1950, construction of major highways through central Brazil, new fertilization techniques and the low cost of land helped to open the Cerrado as a new agricultural frontier, increasing human impact dramatically (Cavalcanti and Joly 2002). This biome is recognized as a global biodiversity hotspot (Myers et al. 2000), having especially high levels of endemism among plants.

In this paper, we used macro-scale biogeographical data (extents of occurrence) to select networks of priority areas to conserve Psittacines in the Cerrado biome, incorporating human population size as a constraint during the selection procedure. Our purpose was to evaluate the possibility of minimizing human-conservation conflicts in the reserve selection procedure. Although broad-scale approaches are usually considered too coarse to establish reserve networks, they can furnish overall guidelines for downscaled conservation strategies and help in defining the focus for more local and effective conservation efforts, especially within the new framework of 'conservation biogeography' (sensu Whittaker et al. 2005). This hierarchical approach may be particularly useful in regions of the world, such as the Brazilian Cerrado, that are still suffering high rates of habitat losses.

\section{Methods}

We used 33 species of Psittacidae that breed in the Cerrado continuous area (see Silva 1995a; Appendix). Although a real network of priority areas selected only with Psittacine data would not be wholly appropriate because other taxa should be considered, we used this group as a model to evaluate the possibility of minimization of human population at a macroecological scale. In any case, several species of this group are at risk of extinction due to domestication, hunting and natural habitat conversion (Sick 1997, IUCN 2004).

A grid with 181 cells with a spatial resolution of $I^{\circ}$ was overlaid on the Cerrado biome map (see Brazil 1999; Figure 1). This grid can be used as a first assessment of priority areas at broad spatial scales. The extent of occurrence of each species was mapped on this grid, based on distribution maps provided by del Hoyo et al. (1997) and Juniper and Parr (1998). Species richness was estimated by counting the overlap of the geographic ranges of the 33 species for each of the 181 cells. Although datasets based on extents of occurrence may be have limited usefulness in conservation-based biodiversity assessments (see Blackburn and Gaston 1998), they may be useful for preliminary evaluations at broad spatial scales (Diniz-Filho et al. 2004). Also, previous analyses with South American Psittacines (Mathias et al. 2004) showed that these broad-scale macroecological patterns are not particularly sensitive to changes in data sources and taxonomic variations.

Human population data were obtained from the Brazilian Institute of Geography \& Statistics (IBGE) demographic census for the year 2000. Population size was calculated for the 181 cells summing the urban and rural population of the 1,054 counties whose political limits are within the Cerrado. These data on human populations were log-transformed to normalize statistical distributions and homogenize their variances. 


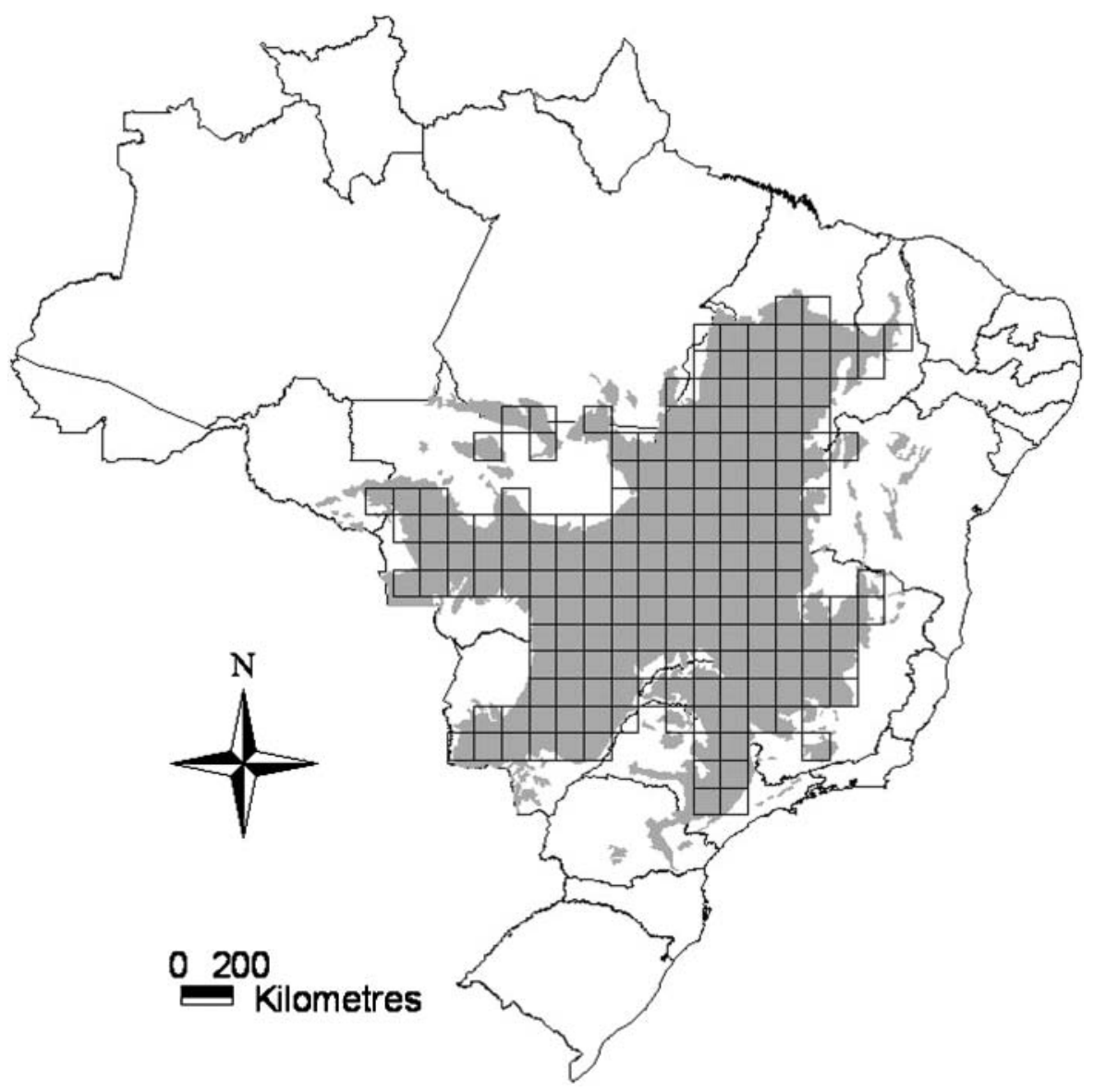

Figure 1 . Grid with 181 cells with a spatial resolution of $I^{\circ}$ overlaid on the Cerrado biome.

The Pearson product-moment correlation between population size and Psittacine species richness was evaluated to assess potential conservation conflicts. Optimization routines using a simulated annealing procedure were used to solve the set-covering problem (Andelman et al. 1999, Cabeza and Moilanen 2001), i.e. to represent each species at least once with a minimum total number of cells. Two approaches were used to select reserve networks of priority areas: (A) a simple approach in which species loss and a cell inclusion have the same cost; (B) a conflict minimization approach, in which the loss-of-species cost is fixed but the cell cost varies with human population size. We varied costs linearly with the log of human population, with the smallest log-human population (3.17) being equal to 0.4 , whereas the largest log-human population (6.45) was equal to 2.0, and then adjusted a linear function (cost $=-1.1353+0.4846$ * human population size $(\ln ))$ to obtain the other cost values. This linearization was done to rescale human population to values comparable to the species cost, ranging from 0.4 to 1 . The simulated annealing algorithm was run 100 times. This algorithm begins with a random set of reserves, and at each iteration it swaps sites in and out of that set, measuring the change in cost according to the following function: Total cost $=\Sigma$ Cost site $i+\Sigma$ Penalty cost for species $j$ not represented, where $i=181$ cells and $j=33$ species. The solutions with smaller costs and with all species represented were retained. 
To determine whether the networks of priority areas selected represent areas with larger human population densities than expected by chance alone, the human population size for each solution was calculated by summing human populations across cells within the proposed network. These values were compared with the total human population found for 100,000 networks randomly selected, with the same number of cells defined by the simulated annealing algorithm. This procedure generated a null distribution. Randomization was performed with the RRS (Randomization Reserve Selection) software (Rangel et al. 2004).

\section{Results}

The maps of human population size and Psittacine species richness distribution in the cells did not have a similar spatial configuration (Figure 2). This was confirmed by the weak negative correlation between these two variables $(r=-0.36)$. There was a clear spatial pattern of species richness in the region, with the highest values concentrated in the west and the north-east. The extreme southern and northern regions were the poorest in species. The human population size is clearly higher in the south and south-east regions. The other cells with many individuals were isolated.

According to the simulated annealing algorithm, the most efficient networks of priority areas for the two approaches were both composed of four cells (Figure 3). In the first approach, several different solutions (57 of 100 runs) have four cells, the smaller network of priority areas possible, and we present here the irreplaceability map, which shows the number of times each cell occurred in all the solutions considered (Figure 3a). Two of them occurred in all networks and are located in Rondônia (NW) and Minas Gerais (E). The other cells varied between networks, but variation occurred in the north-west and generally in the southern regions. In the reserve selection approach that minimized the human population, there was just one solution with a smaller possible cost (Figure 3 b). The cells selected minimizing human population encompass the states of Rondônia (NW), Mato Grosso (NW), Minas Gerais (E) and Mato Grosso do Sul (SW). The two cells that occurred in all the solutions without human population cost were also selected in this reserve network. When human population density was incorporated into the optimization function, the optimal reserve network of priority areas contained approximately $17 \%(106,820)$ of the average of population in the selection approach that did not include human population density as a cost $(622,122.89)$.
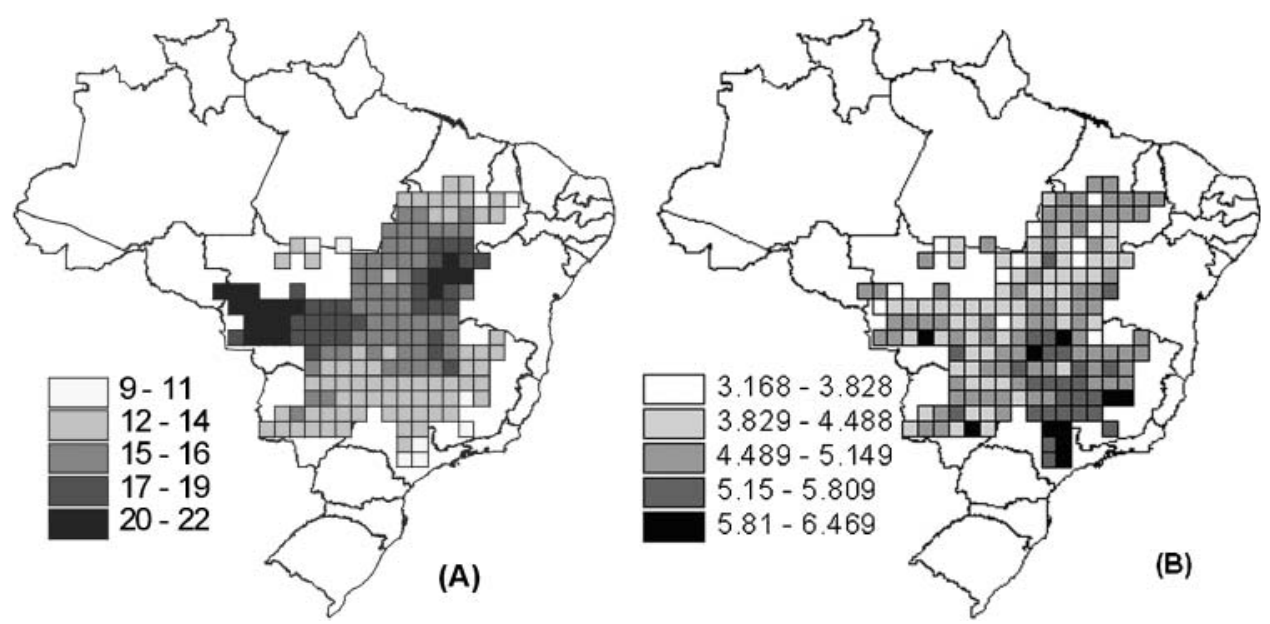

Figure 2. Spatial patterns of (a) parrot species richness (number of different species) and (b) human population size (in number of individuals at log scale) across the Brazilian Cerrado. 

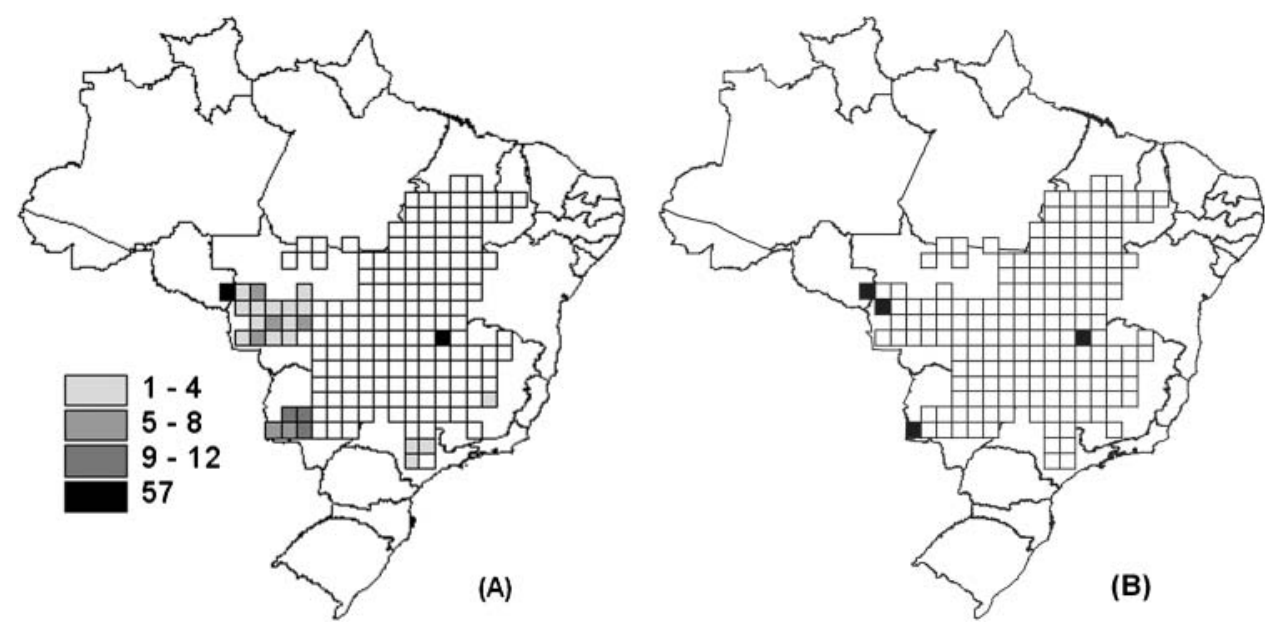

Figure 3. The cells selected from the simulated annealing algorithm applied to parrot presence and absence matrix in the Brazilian Cerrado, with (a) scenario A, which does not incorporate cost in the cells, showing the irreplaceability map, i.e. in how many of the 57 different networks each cell occurred, and (b) scenario B, obtained with human population incorporated as a cell cost. The cells selected are shown in black.

Also, it is important to ask how these total human population values within reserve networks of priority areas relate to the human population size in the other cells of the Cerrado biome. We compared these values with the null human population size distribution within four cells randomly chosen in the Cerrado (Figure 4). The average human population size in the networks of priority areas selected without the human population constraint was higher than the average of the null distribution, but not significantly so $(P=0.26)$, and the human population size under the selection process that incorporates this constraint was lower than the average of the null distribution $(P=0.07$, see Figure 4$)$.

\section{Discussion}

The relationship between Psittacine species richness and human population size showed a very weak and negative correlation. This result contrasts with other studies that found a higher and positive correlation between species richness and human population size (Balmford et al. 2001, Araújo 2003, Luck et al. 2004). It is important to note that, because of autocorrelation in the two variables (the lack of independence between pairs of observations at given distances in time or space; Legendre 1993), the significance of this correlation is almost certainly upwardly biased (Diniz-Filho et al. 2003, Diniz-Filho and Bini 2004). Thus, this correlation is probably not statistically different from zero. The absence of a continuous pattern of human population size (Figure $2 b$ ) reflects the occupation of the Cerrado region and Brazil, and would significantly affect the analyses of biodiversity patterns (Diniz-Filho et al. 2005). People are highly concentrated in the more developed south-eastern region and other scattered cells probably represent state centres. This absence of a correlation does not indicate an absence of conservation conflicts when establishing priority areas, especially because complementarity methods can be designed to avoid as much as possible overlap between conservation areas and regions of intense human occupation (Chown et al. 2003, Diniz-Filho et al. 2006).

As already pointed out by Chown et al. (2003), drawing conclusions about conservation conflicts based on species richness and human development correlations (see Balmford et al. 2001) is unwarranted because complementarity values of the areas were not taken into account 


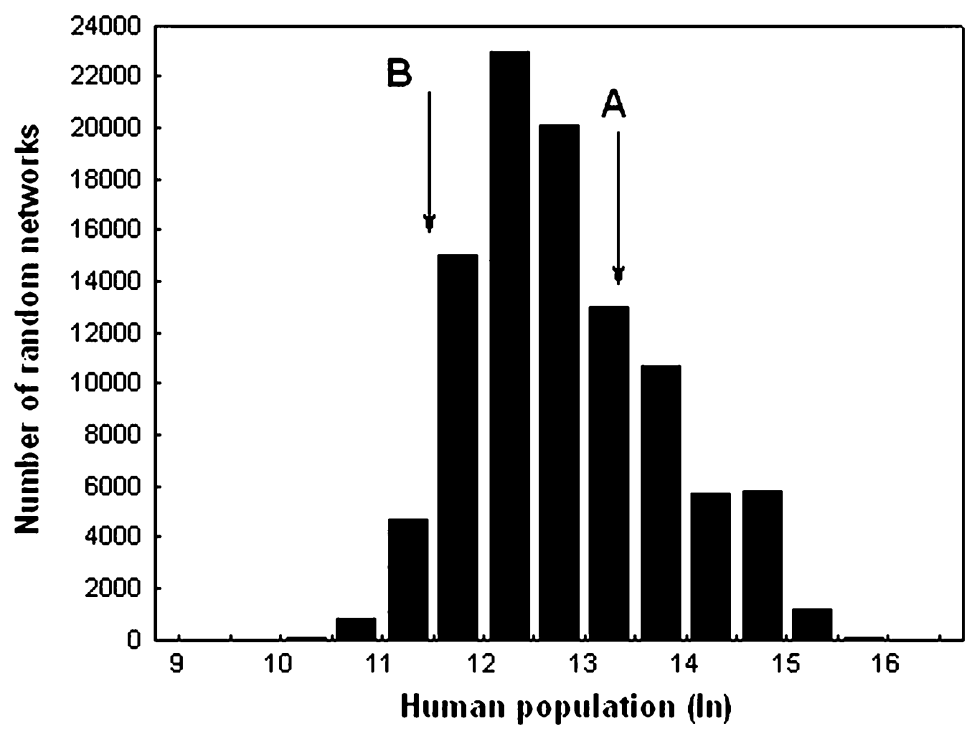

Figure 4. Frequency distribution of total human population size in four cells randomly selected from the grid overlaying the Cerrado biome. The arrows indicate (a) the median of the human population size in 57 different networks selected in scenario A, and (b) the human population size in the networks selected in scenario B with human population size as a constraint.

(but see Moore et al. 2001, and Diniz-Filho et al. 2006 for a recent comparison of the two approaches). We then assessed this question by defining networks of priority areas with the two different approaches (incorporating human population size within cells as a constraint in the selection procedure or not). There were two cells with the same location in the networks selected, which were probably predetermined by species with restricted distribution in the Cerrado. For example, the most restricted species (those occurring in to cells or fewer) in the present analysis are Myiopsitta monachus (9 cells), Pyrrhura pfrimeri (9), Brotogeris tiririca (6) and Brotogeris cyanoptera (I). If we assume that human population directly or indirectly impairs biodiversity (a reasonable assumption) (McKee et al. 2003, Luck et al. 2004), it is better and now absolutely possible to include human population, or any other surrogate variable of human development, as a constraint in the simulated annealing algorithms, finding a different network of priority areas that tries to best compromise species conservation and human development. However, for very restricted species, such as those described above, there is no way to avoid conservation conflicts, if they are restricted to areas with intense human occupation (but see below).

Three of the areas selected in the second approach are the same as those selected in the Priority-setting Workshop (Brazil 1999). Only the cell in Rondônia state (north-west) is different. The richest cell is in Mato Grosso state (W), which contains 22 species. The others in Rondônia (NW), Minas Gerais (E) and Mato Grosso do Sul (SW) have 21, 18 and 13 species, respectively. In the Psittacines' case, there is no need to select more areas to minimize conflicts, and just a new spatial arrangement of the network of priority areas seems to be enough to minimize potential conflicts between conservation and human occupation (Figure 4). Thus, constraining the network with the human population size of the cells is a useful way to select networks of priority areas coherent with human occupation, since species richness and human population are not strongly related, facilitating conservation efforts in the case of Psittacines. The diversity of equally complementary networks of priority areas to represent Psittacines provides some flexibility in the reserve selection procedure. The variation in location of cells selected between the 57 solutions is highly clumped in some regions. Autocorrelation effects 
(Diniz-Filho and Bini 2004) and the beta diversity structure may be influencing this pattern, as already showed by Bini et al. (2004) for amphibians in the same region. Some flexibility was also found in the networks selected by Chown et al. (2003). When human population is incorporated into the reserve selection procedure, the network of priority areas selected that represents all species is not flexible. In any case it is possible to minimize conservation conflicts since a network of priority areas with fewer people than expected by chance was found.

Some methodological issues must be discussed regarding our analyses. A $I^{\circ}$ cell is not a practical size for the management of the species, but important priority areas that should be focused for conservation, in a hierarchical approach, can be identified at this scale. The geographic distance between cells and border effects were not considered; only the representation of each species must be assured. Thus, although the networks of priority areas include some part of the geographic range of all Psittacine species, the viability of populations and long-term persistence were not considered. Further investigations dealing with this issue are required, although they should be more focused on species' attributes and on how different levels of human occupation and activity affect each of these species.

Finally, it is important to evaluate habitat availability in relation to human population size within the Cerrado region. This is not as explicit in this biome as was found in Africa (Chown et al. 2003), where high population densities clearly translate into considerable landscape transformation. In the Cerrado, the opposite may occur, since large farms using advanced agricultural technology (Fearnside 2001, Klink and Moreira 2002) can produce a major transformation of the landscape, although it may be not densely populated. Studies examining the efficiency of human population size as a surrogate for human development and land-cover changes, and investigating the relationship between these variables, are necessary to help conservation planners with strategies that minimize conservation conflicts.

\section{Acknowledgements}

Thiago Fernando L. B. V. Rangel (t.rangel@terra.com.br) kindly provided the RRS software, and Mário Barroso Neto (Conservation International - Brazil) the basic grid overlaying the Cerrado in Brazil. This work was supported by a PRONEX programme of CNPq, SECTEC-GO (proc. 23234156) for establishing conservation priorities in the Brazilian Cerrado. M. P. P. is supported by a SIAD (Integrated System of Deforestation Alert - UFG/SIPAM accord) fellowship, while D. B., J. A. F. D.-F. and L. M. B. are supported by doctoral and researcher CNPq fellowships.

\section{Appendix. Species considered in the reserve selection procedure, common name and status on IUCN red list}

LC, Least Concern; NT, Near Threatened; EN, Endangered; *, not on IUCN red list.

\begin{tabular}{lll}
\hline Species & Common name & Species status (IUCN) \\
\hline Amazona aestiva & Blue-fronted Parrot & LC \\
Amazona amazonica & Orange-winged Parrot & LC \\
Amazona farinose & Mealy Parrot & LC \\
Amazona xanthops & Yellow-faced Parrot & NT \\
Anodorhynchus hyacinthinus & Hyacinth Macaw & EN \\
Ara ararauna & Blue-and-yellow Macaw & LC \\
Ara auricollis & Yellow-collared Macaw & $*$ \\
Ara chloropterus & Red-and-green Macaw & LC \\
Ara macao & Scarlet Macaw & LC \\
Ara manilatus & Red-bellied Macaw & LC \\
Ara maracana & Illiger's Macaw & $*$ \\
Ara nobilis & Red-shouldered Macaw & LC \\
Ara severus & Chestnut-fronted Macaw & LC \\
\hline
\end{tabular}




\begin{tabular}{lll}
\hline Species & Common name & Species status (IUCN) \\
\hline Aratinga acuticaudata & Blue-crowned Parakeet & LC \\
Aratinga aurea & Peach-fronted Parakeet & LC \\
Aratinga auricapillus & Golden-capped Parakeet & NT \\
Aratinga cactorum & Cactus Parakeet & LC \\
Aratinga jandaya & Jandaya Parakeet & LC \\
Aratinga leucophthalma & White-eyed Parakeet & LC \\
Aratinga weddellii & Dusky-headed Parakeet & LC \\
Brotogeris chiriri & Yellow-chevroned Parakeet & LC \\
Brotogeris cyanoptera & Cobalt-winged Parakeet & LC \\
Brotogeris tirica & Plain Parakeet & LC \\
Forpus xanthopterygius & Blue-winged Perrotlet & LC \\
Myiopsitta monachus & Monk Parakeet & LC \\
Pionus maximiliani & Scaly-headed Parrot & LC \\
Pionus menstruus & Blue-headed Parrot & LC \\
Pyrrhura devillei & Blaze-winged Parakeet & LC \\
Pyrrhura frontalis & Maroon-bellied Parakeet & LC \\
Pyrrhura molinae & Green-cheeked Parakeet & LC \\
Pyrrhura pfrimeri & Pfrimeŕs Parakeet & $*$ \\
Pyrrhura picta & Painted Parakeet & LC \\
Pyrrhura rhodogaster & Crimson-bellied Parakeet & $*$ \\
\hline
\end{tabular}

\section{References}

Andelman, S., Ball, I., Davis, F. and Stoms, D. (1999) SITES v. 1.o. An analytical toolbox for designing ecoregional conservation portfolios. Technical report, The Nature Conservancy. http://www.biogeog.ucsb. edu/projects/tnc/toolbox.html.

Araújo, M. B. (2003) The coincidence of people and biodiversity in Europe. Global Ecol. Biogeogr. 12: 5-12.

Araújo, M. B. and Williams, P. (200o) Selecting areas for species persistence using occurrence data. Biol. Conserv. 96: 331-345.

Balmford, A., Moore, J. L., Brooks, T., Burgess, N., Hansen, L. A., Williams, P. and Rahbek, C. (2001) Conservation conflicts across Africa. Science 291: 2616-2619.

Balmford, A., Bruner, A., Cooper, P., Costanza, R., Farber, S., Green, R. E., Jenkins, M., Jefferiss, P., Jessamy, V., Madden, J., Munro, K., Myers, N., Naeem, S., Paavola, J., Rayment, M., Rosendo, S., Roughgarden, J., Trumper, K. and Turner, R. K. (2002) Economic reasons for conserving wild nature. Science 297: 950-953.

Bini, L. M., Diniz-Filho, J. A. F., Pinto, M. P., Silva, M. S. D., Carvalho, P., Rangel, T. F.
L. V. B. and Bastos, R. P. (2004) Estabilidade dos algoritmos de seleção de unidades de conservação em relação à diversidade beta de anfíbios anuros no Cerrado. Pp. 234-240 in Anais IV Congresso Brasileiro de Unidades de Conservação. Volume II. Curitiba: Fundação o Boticário de Proteção à Natureza, Rede Nacional Pró Unidades de Conservação.

BirdLife International (2004) List of globally threatened birds. www.birdlife.org.

Blackburn, T. M. and Gaston, K. J. (1998) Some methodological issues in macroecology. Am. Nat. 151: 68-83.

Brazil (1999) Ações prioritárias para conservação da biodiversidade do cerrado e pantanal. Brasilia: MMA/Funatura/Conservation International/Biodiversitas/Unb.

Brooks, T. M., Mittermeier, R. A., Mittermeier, C. G., Fonseca, G. A. B., Rylands, A. B., Konstant, W. R., Flick, P., Pilgrim, J., Oldfield, S., Magin, G. and Hilton-Taylor, C. (2002) Habitat loss and extinction in the hotspots of biodiversity. Conserv. Biol. 16: 909-923.

Cabeza, M. and Moilanen, A. (2001) Design of reserve network and the persistence of 
biodiversity. Trends Ecol. Evol. 16: 242-248.

Cavalcanti, R. B. (1999) Bird species richness and conservation in the cerrado region of central Brazil. Stud. Avian Biol. 19: 244-249.

Cavalcanti, R. B. and Joly, C. A. (2002) Biodiversity and conservation priorities in the cerrado region. Pp. $351-367$ in P. S. Oliveira and R. J. Marquis, eds. The cerrados of Brazil: ecology and natural history of a Neotropical savanna. New York: Columbia University Press.

Chown, S. L., van Rensburg, B. J., Gaston, K. J., Rodrigues, A. S. L. and van Jaarsveld, A. S. (2003) Energy, species richness, and human population size: conservation implications at a national scale. Ecol. Appl. 13: 1233-1241.

Csuti, B., Polasky, S., Williams, P. H., Pressey, R. L., Camm, J. D., Kershaw, M., Kiester, A. R., Downs, B., Hamilton, R., Huso, M. and Sahr, K. (1997) A comparison of reserve selection algorithms using data on terrestrial vertebrates in Oregon. Biol. Conserv. 80: 83-97.

del Hoyo, J., Elliot, A. and Sargatal, J., eds. (1997) Handbook of the birds of the world: sandgrouse to cuckoos. Volume 4. Barcelona: Lynx Edicions.

Diniz-Filho, J. A. F. and Bini, L. M. (2004) Autocorrelação espacial, gap analysis e métodos de complementaridade para seleção de unidades de conservação. Pp. 16-28 in Anais IV Congresso Brasileiro de Unidades de Conservação. Volume II. Curitiba: Fundação o Boticário de Proteção à Natureza, Rede Nacional Pró Unidades de Conservação.

Diniz-Filho, J. A. F., Bini, L. M. and Hawkins, B. A. (2003) Spatial autocorrelation and red herrings in geographical ecology. Global Ecol. Biogeogr. 12: 53-64.

Diniz-Filho, J. A. F., Bini, L. M., Vieira, C. M., Souza, M. C., Bastos, R. P., Brandão, D. and Oliveira, L. G. (2004) Spatial patterns in species richness and priority areas for conservation of anurans in the Cerrado region, Central Brazil. Amph.-Reptilia 25: 63-75.

Diniz-Filho, J. A. F., Bastos, R. P., Rangel, T. F. L. V. B., Bini, L. M., Carvalho, P. and
Silva, R. J. (2005) Macroecological correlates and spatial patterns of anurans description dates in Brazilian Cerrado. Global Ecol. Biogeogr. 14: 469-477.

Diniz-Filho, J. A. F., Bini, L. M., Pinto, M. P., Rangel, T. F. L. V. B., Carvalho, P. and Bastos, R. P. (2006) Anuran species richness, complementarity and conservation conflicts in Brazilian Cerrado. Acta Oecol. 29: 9-15.

Fearnside, P. M. (2001) Soybean cultivation as a threat to the environment in Brazil. Environ. Conserv. 28: 23-38.

Howard, P. C., Viskanic, P., Davenport, T. R. B., Kigenyi, F. W., Baltzer, M., Dickinson, C. J., Lwanga, J. S., Matthews, R. A. and Balmford, A. (1998) Complementarity and the use of indicator groups for reserve selection in Uganda. Nature 394: 472-475.

International Union for Conservation of Nature (IUCN) (2004) Red list of threatened species. www.redlist.org

Juniper, T. and Parr, M. (1998) Parrots: $a$ guide to the parrots of the world. London: Yale University Press.

Klink, C. A. and Machado, R. B. (2005) Conservation of the Brazilian cerrado. Conserv. Biol. 19: 707-713.

Klink, C. A. and Moreira, A. G. (2002) Past and current human occupation, and land use. Pp. $69-88$ in P. S. Oliveira and R. J. Marquis, eds. The cerrados of Brazil: ecology and natural history of a Neotropical savanna. New York: Columbia University Press.

Lawler, J. J., White, D. and Master, L. L. (2003) Integrating representation and vulnerability: two approaches for prioritizing areas for conservation. Ecol. Appl. 13: $1762-1772$.

Legendre, P. (1993) Spatial autocorrelation: trouble or new paradigm? Ecology 74: 1659-1673.

Luck, G. W., Ricketts, T. H., Daily, G. C. and Imhoff, M. (2004) Alleviating spatial conflicts between people and biodiversity. Proc. Natl. Acad. Sci. USA 101: 182-186.

Margules, C. R., Nicholls, A. O. and Pressey, R. L. (1988) Selecting networks of reserves to maximise biological diversity. Biol. Conserv. 43: 63-76. 
Mathias, P. V. C., Mendonça, C. V., Rangel, T. F. L. V. B. and Diniz-Filho, J. A. F. (2004) Sensitivity of macroecological patterns of South American parrots to differences in data sources. Global Ecol. Biogeogr. 13: 193-198.

McKee, J. K., Sciulli, P. W., Fooce, C. D. and Waite, T. A. (2003) Forecasting global biodiversity threats associated with human population growth. Biol. Conserv. 115: 161-164.

Moore, L., Balmford, A., Brooks, T., Burgess, N., Folkmann, M., Hansen, A., Krarup, J., Lovett, J. C., Tokumine, S., Williams, P., Woodward, F. I. and Rahbek, C. (2001) Complementarity analysis reveal extent of conservation conflict in Africa. Science 293: 1591-1592.

Myers, N., Mittermeier, R. A., Mittermeier, C. G., Fonseca, G. A. B. and Kent, J. (2000) Biodiversity hotspots for conservation priorities. Nature 403: 853-858.

Pressey, R. L., Humphries, C. J., Margules, C. R., Vane-Wright, R. I. and Williams, P. H. (1993) Beyond opportunism: key principles for systematic reserve selection. Trends Ecol. Evol. 8: 124-128.

Rangel, T. F. L. V. B., Pinto, M. P., DinizFilho, J. A. F. and Bini, L. M. (2004) Avaliação da eficiência de unidades de conservação através de teste de aleatorização. Pp. 161-168 in Anais IV Congresso Brasileiro de Unidades de Conservação. Curitiba: Fundação o Boticário de Proteção à Natureza, Rede Nacional Pró Unidades de Conservação.

Sick, H. (1997) Ornitologia brasileira. Second edition. Rio de Janeiro: Editora Nova Fronteira.

Silva, J. M. C. (1995a) Birds of the cerrado region, South America. Steenstrupia 21: 69-92.

Silva, J. M. C. (1995b) Avian inventory of cerrado region, South America: implications for biological conservation. Bird Conserv. Int. 5: 292-304.

Tubelis, D. P. and Cavalcanti, R. B. (2000) A comparison of bird communities in natural and disturbed non-wetland open habitats in the Cerrado's central region, Brazil. Bird Conserv. Int. 10: 331-350.

Vitousek, P. M., Mooney, H. A., Lubchenco, J. and Melillo, J. M. (1997) Human domination of earth's ecosystems. Science 277: 494-499.

Whittaker, R. J., Araújo, M. B., Paul, J., Ladle, R. J., Watson, J. E. M. and Willis, K. J. (2005) Conservation biogeography: assessment and prospect. Divers. Distrib. 11: 3-23.

\section{MÍRIAM PLAZA PINTO*, PABLO VINÍCIUS CLEMENTE MATHIAS}

Programa de Pós-Graduação em Ecologia e Evolução, ICB, Universidade Federal de Goiás, Brazil.

\section{DANIEL BLAMIRES}

Programa de Pós-Graduação em Ciências Ambientais, Universidade Federal de Goiás, Brazil.

JOSÉ ALEXANDRE FELIZOLA DINIZ-FILHO†, LUIS. MAURICIO BINI

Departamento de Biologia, ICB, Universidade Federal de Goiás, Brazil.

*Author for correspondence. Current address: Programa de Pós-Graduação em Ecologia, Laboratório de Vertebrados, Departamento de Ecologia, IB, UFRJ, Brazil; e-mail: miriamplazapinto@ yahoo.com.br

†Current address: Departamento de Biologia, MCAS/PROPE, Universidade Católica de Goiás, Brazil. 